https://doi.org/10.5800/GT-2017-8-3-0296

\title{
BASIC PRINCIPLES OF STRUCTURAL AND HYDROGEOLOGICAL MAPPING OF THE BAIKAL REGION
}

\author{
M. A. Tugarina1, K. Zh. Seminsky² \\ ${ }^{1}$ Irkutsk National Research Technical University, Irkutsk, Russia \\ ${ }^{2}$ Institute of the Earth's Crust, Siberian Branch of RAS, Irkutsk, Russia
}

For citation: Tugarina M.A., Seminsky K.Zh., 2017. Basic principles of structural and hydrogeological mapping of the Baikal region. Geodynamics \& Tectonophysics 8 (3), 577-579. doi:10.5800/GT-2017-8-3-0296.

Structural and hydrogeological zonation of the Baikal region is based on allocation of hydrogeological structures within the large tectonic complexes differing in development history. It is a southeast part of the $\mathrm{Si}$ berian platform, the Sayan-Baikalian folded belt and the western part of the Transbaikal folded region. The Cenozoic activation of the region which has led to emergence of the Baikal rift and movements on a series of large fault zones in Transbaikalia has substantially influenced on formation of collecting properties of rocks.

The hydrogeological structure is understood as a geological body in which borders the nature of underground waters' distribution remains continuous as well as conditions of formation of their resources and composition [Stepanov, 1980]. Hydrogeological massifs are the blocks of crust of modern mountains lifted above basis of erosion. In borders of massifs the weathering processes promoting disclosure of fractures and destruction of rocks actively develop.

Hydrogeological basins are the hydrogeological structures having a block structure presented by stratal reservoir rocks (collectors) of underground waters in a sedimentary cover below basis of erosion. Waterbearing faults are open segments in fault zones watered or permeable for water.

Spatial position of hydrogeological structures allows, unlike traditional approaches, with higher objec- 
tivity to estimate conditions of underground water distribution in a wide number of practical tasks.

Methods of researches. Allocation of hydrogeological structures is based on the principles of the structural and hydrogeological analysis and systematization of hydrogeological structures [Stepanov, 1989] with use of geological, structural and tectonophysical approach to assessment of collecting properties of rocks.

Results and prospects of researches. In the Baikal region crystal, metamorphogenic and volcanogenic hydrogeological massifs; platform, marginal and intermountain hydrogeological basins and also the waterbearing fault zones having various hydrogeological value are allocated.

Hydrogeological massifs of the Baikal region were created along deep tectonic suture. Influence of hypergene processes on collecting properties of rocks formation in a weathering zone is shown differently depending on type of rock and grade of its metamorphic processing.

Crystal hydrogeological massifs are formed by Paleozoic magmatic rocks and also ancient highly metamorphized (recrystallized) rocks of the Proterozoic and Archean. They differ in rather uniform structural and mechanical properties and, congruently the same response of rocks to influence of weathering factors. The intensity of fracturing increases near faults. In a vertical section regional zones of open fissures gradually fade and at a certain depth pass into a zone of separate often impenetrable fractures. Underground waters are spread in a weathering zone in magmatic igneous and ancient metamorphic rocks up to the depth of 20-30 m and more rarely $-60-80 \mathrm{~m}$. Ground water discharge is small and make the hundredth or tenth shares of liter per second, seldom reaching $1.5 \mathrm{l} / \mathrm{s}$.

Metamorphogenic hydrogeological massifs are formed by Precambrian metamorphic and lithified Carboniferous and Jurassic sedimentary rocks. Complex character of fracture collectors in weathering zone and existence of strata fragments with nonuniform permeability predetermined an alternation of aquiclude and permeable fractured layers. Depth of open fractures changes from 20 to $80 \mathrm{~m}$. Yields of springs are extremely low, occasionally reach $2-3 \mathrm{l} / \mathrm{s}$.

Volcanogenic hydrogeological massifs are dated for lava streams, covers and presented by dome forms in orogenic structures and activated platform areas. The most extensive on the area volcanogenic massifs are widespread in Transbaikalia and East Sayan Mountains. Their thickness can reach several hundred meters. In a structure of massifs it is noted from one to several lava covers which alternate by sedimentary material. The multilayered structure has caused a level arrangement of the water-bearing layers separated by aquicludes. Springs' yields don't exceed 1-3 l/s, reaching in rare instances $10 \mathrm{l} / \mathrm{s}$.
Hydrogeological basins in the Baikal region are subdivided into three types: platform, marginal and intermountain.

Platform basins' features are huge areas (hundreds of thousands of square kilometers) and considerable thickness (to the first tens of kilometers). AngaroLensky, Tungus and Yakut basins were created within syneclises with a heterogeneous sedimentary cover under the influence of fracturing and block movements of the platform basement. The main water containing rocks are terrigenous and carbonate deposits of the lower Paleozoic. Their water abundance is characterized by yields of springs from the 100-th shares to hundreds of liters per second. The mineralization of underground waters increases with depth from 0.2 to $34.0 \mathrm{~g} / \mathrm{dm}^{3}$.

Marginal hydrogeological basins are dated for marginal depressions on border of platform and mountain areas. They lean towards the base blocks down casted on depth to several kilometers or represent local structures, quite often hydraulically separated.

Intermountain hydrogeological basins were formed as graben structures along large faults in mountain and folded areas and are filled with orogenic sediments. The block structure of depressions' base has caused complex structure of intermountain basins and the irregular sedimentation. Hydrogeological conditions of intermountain basins are defined by the leading role of fractures, lack of the sustained aquifers and specific conditions of water exchange.

Hydrogeological structures of the water-bearing faults are characterized by underground waters' discharges, various on yield, pressure head, mineralization, chemical and gas composition and also on a role in water inflows to mines.

Allocation as special type of hydrogeological structures of fracture-veined collectors in water-bearing faults or supposed water-bearing faults is based on tectonophysical understanding of the last one as wide zones of the fractures of the 2nd order which are genetically connected with formation of the main fault (the 1st order) [Sherman et al., 1983; Seminsky, 2003]. The newest fault structures of the 2nd and higher order created or activated in the Cenozoic are referred to water-bearing fault zones.

On the basis of the above mentioned principles the original structural and hydrogeological map of the Baikal region in scale 1:3000000 has been composed. Hydrogeological structures with specific conditions of formation of underground waters collectors are reflected. The map is useful in working at various practical tasks.

Acknowledgements. Work has been done at partial support of the Russian Foundation for Basic Research (No. 16-55-44017). 


\section{REFERENCES}

Seminsky K.Zh., 2003. Internal Structure of Continental Fault Zones. Tectophysical Aspect. Siberian Branch of the Russian Academy of Science, Publishing House Branch "Geo", Novosibirsk, $244 \mathrm{p}$.

Sherman S.I., Bornyakov S.A., Buddo V.Yu., 1983. Areas of Dynamic Influence of Faults (Results of Modeling). Nauka, Novosibirsk, $112 \mathrm{p}$.

Stepanov V.M., 1980. Hydrogeological Structures of Transbaikalia. Nedra, Moscow, 176 p.

Stepanov V.M., 1989. Introduction to Structural Hydrogeology. Nedra, Moscow, 229 p. 